Journal of Accident and Emergency Medicine 1995

$12,30-31$
Correspondence:

M.J. Horrocks,

Professor of Surgery, Royal United Hospital, Combe Park, Bath BA1 3NG, UK

\title{
The Glastonbury Festival 1993: pattern of attendances and admissions to an NHS Trust
}

\author{
S. BRITTEN, ${ }^{1}$ M.S. WHITELEY, ${ }^{2}$ P.F.FOX, ${ }^{3}$ M.I.GOODWIN ${ }^{1}$ \& \\ M.J. HORROCKS ${ }^{2}$
}

Departments of ${ }^{1}$ Orthopaedic Surgery, ${ }^{2}$ Surgery and ${ }^{3}$ Accident and Emergency Medicine, Royal United Hospital, Combe Park, Bath

\section{INTRODUCTION}

The Glastonbury Festival is an annual event attracting an attendance of 85000 people. The 1993 Festival ran from Friday 25 June to Sunday 27 June inclusive. Each attendee to Bath's Royal United Hospital from the Glastonbury Festival site was identified prospectively. Data collected included the number of attendees and the number of those who were admitted, the treatments provided by this Trust and the total number of days stay of patients in the intensive care unit and in ward beds.

Key words: health care provider, Glastonbury festival, music festival, NHS trusts, outdoor crowd event.

\section{RESULTS}

Pattern of attendances and admissions

Over the 1-week period surrounding the Festival, the Royal United Hospital NHS Trust saw 53 patients from the Festival; 24 (45\%) of these were admitted.

Admissions. The specialty under which each of these 24 patients was admitted is shown in Table 1. The average age of these patients was 24.1 years (range $2-37$ ), there was a male:female ratio of $15: 9$ and only two $(8 \%)$ patients were children. Seventeen $(71 \%)$ of the patients who were admitted had seen an on-site doctor and had brought a letter of referral with them.

In total, at least seven (29\%) admissions were known to be drugs related and three $(13 \%)$ were the result of an assault. Four (17\%) of these patients required overnight observation only, while four $(17 \%)$ required transfer to the intensive care unit (ICU) for at least 1 night. Nine (38\%) patients were still in hospital 1 week after admission.

Ten $(42 \%)$ patients required a total of 16 operations taking up $24 \mathrm{~h}$ of operating theatre time. Three $(13 \%)$ patients required in-patient care of longer
Table 1. Admissions to the Royal United Hospital Trust from the Glastonbury Festival, by specialty

\begin{tabular}{lc}
\hline Specialty & No. of patients \\
\hline Medicine & 8 \\
General surgery & 5 \\
Orthopaedics & 4 \\
Gynaecology & 4 \\
Psychiatry & 2 \\
Paediatrics & 1 \\
Total & 24 \\
\hline
\end{tabular}

than 1 month after admission. The number of days of in-patient ward care totalled 364 days and in addition, 31 days of ICU care were required.

Attenders not admitted. A total of 29 patients were examined in the accident and emergency (A\&E) department and were discharged. Five (17\%) required further fracture clinic follow-up whilst two (7\%) required an eye clinic out-patient appointment. Of those patients who were fit to discharge, four $(14 \%)$ attendances were definitely known to be drug related and two $(7 \%)$ were the result of an assault. Twenty-one (72\%) patients required a radiograph, six $(21 \%)$ having sustained an inversion injury to their ankle and five (17\%) had a fracture or dislocation shown by radiograph. Two $(7 \%)$ patients were requesting a prescription only.

\section{DISCUSSION}

Fifty-three patients were seen at this hospital from the Glastonbury Festival over a 1-week period. The rate of admission is far higher than would be expected in our normal practice and this may be explained by the filtering out of trivial complaints by the organized medical care on site, which consisted of a rota of medical practitioners, nursing and paramedical staff. Of those patients discharged from

(C) 1995 BlackweH Science Ltd 
the A\&E department, 21 (72\%) required a radiograph, a service which was not available on-site.

It is not surprising that the attending population was young, with a mean age of 24.4 years. Of more interest however was the low level of serious violence, with only five $(9 \%)$ of the 53 patients having been assaulted. However, in contrast to this, at least seven $(29 \%)$ patient admissions were related to the use of illicit drugs.

The results of this study show that there was substantial morbidity associated with the Glaston- bury Festival that was seen at this Hospital Trust. This morbidity carries with it a sizeable financial burden to the Trust and to the wider National Health Service. ${ }^{1}$

\section{REFERENCE}

1. Britten S., Whiteley M.S., Fox P.F., Goodwin M.I. \& Horrocks M. (1993) The transitory influx of patients to the Glastonbury Festival. British Medical Journal 307, 561. 